\title{
Postcolonial Interjections: Jean-Philippe Stassen Illustrates Heart of Darkness and We Killed Mangy-Dog
}

\author{
Michelle Bumatay \\ Willamette University
}

In 2006, internationally acclaimed Belgian cartoonist Jean-Philippe Stassen produced new editions of two well-known books from the European colonial era - Joseph Conrad's Caur des ténèbres [Heart of Darkness] ${ }^{1}$ first published over the course of three months in the spring of 1899 and Luis Bernardo Honwana's Nous avons tué le Chien Teigneux [We Killed Mangy-Dog] ${ }^{2}$ originally published in a collection of Honwana's short stories in 1964. These new publications feature original illustrations by Stassen and can be seen as continuing a larger trend in which established artists illustrate classic literature to showcase their talents such as Gustave Doré's treatments of Dante's Divine Comedy and Rabelais's La vie de Gargantua et de Pantagruel, both of which were also later illustrated by Salvador Dalí. While these projects were often commissioned works (in the case of Doré), they were also opportunities to reconfigure popular cultural icons (in the case of Dali). By selecting, imagining, and illustrating scenes from well-known texts, these artists, and Stassen in turn, comment on the original texts. Unlike adaptations that alter original source material into another genre, Stassen's treatments of Heart of Darkness and We Killed Mangy-Dog function more as a commentary across time and space ${ }^{3}$. This article considers how Stassen enters into dialogue with the original texts through his interjections, thus exploring gaps and short-comings in Conrad's Heart of Darkness and silences and the subtle power of the piercing eye in Honwana's allegorical We Killed Mangy-Dog.

In contrast to adaptations that creatively transpose original texts into new genres and mediums, these new editions of Heart of Darkness and We Killed Mangy-Dog, apart from being translated into French, do not change Conrad's and Honwana's respective writings; rather, Stassen's interjections across time

${ }^{1}$ All translations of Heart of Darkness, unless otherwise stated, come from Youth: A Narrative and Two Other Stories, by Joseph Conrad and edited with an introduction by Mortan Dauwen Zabel (1959).

2 All English translations of Nous avons tué le Chien Teigneux are my own.

${ }^{3}$ In contrast to the two texts considered in this article, L'île au trésor (2012), a bande dessinée written by Sylvain Venayre and illustrated by Stassen, is an actual adaptation of Robert Louis Stevenson's adventure novel, Treasure Island, originally published in its entirety in 1883. In addition to converting the novel into a graphic narrative, the adaptation also updates the narrative by transposing it to contemporary France. 
and space are best understood as sets of paratextual practices. According to Gerard Genette in his influential Paratexts: Thresholds of Interpretation, paratexts, which are "made up of a heterogeneous group of practices and discourses of all kinds and dating from all periods" (2), vary widely and are unique to each text and even to each edition of a given text. Such heterogeneous practices and discourses exert differing influences on texts and the ways in which readers approach them. Subsequently, as Genette stresses, to understand the multifaceted signification of a given paratext necessarily includes determining each of the contributing elements'

location (the question where?); the date of its appearance and, if need be, its disappearance (when?); its mode of existence, verbal or other (bow?); the characteristics of its situation of communication - its sender and addressee (from whom? to whom?); and the functions that its message aims to fulfill (to do what?)" (Genette 4)

This set of questions is essential for determining what Stassen does to the original texts, how he does it, and, most importantly, how such practices work to reshape our understanding of Heart of Darkness and We Killed Mangy-Dog. Indeed, though the question of when in these two cases is relatively the same-despite being separated by approximately sixty years, both texts hail from the colonial era-and though Stassen uses a contemporary lens through which to revisit these previously published texts, the rest of his paratextual practices for each text, including the two texts' physical formats and the added illustrations, differ quite drastically.

\section{1) Addressing the Gaps in Heart of Darkness}

Published jointly by Gallimard and Futuropolis, the new edition of Joseph Conrad's Heart of Darkness is formatted and packaged in the exact same manner as Gallimard's graphic novel collection-Bayou (directed by Joann Sfar)—despite not being an actual graphic novel. The hardback book, though slightly smaller than a mainstream bande dessinée, is nevertheless much longer than the standard forty-eight pages. Likewise, while the thick, glossy paper used resembles that of regular bandes dessinées, the overall layout of the book and the high quality reproduction of Stassen's illustrations evoke an artist's book aesthetic. Moreover, the illustrations themselves are not simple drawings depicting various scenes from Conrad's text. Rather, Stassen has created twenty full-page paintings encapsulated in a hand-drawn black frame much like a splash page from a graphic narrative, each captioned with a hand-picked quotation or fragment of a quotation from the novel. Spaced evenly throughout Heart of Darkness every four pages and always on a verso or lefthanded page, the twenty illustrations and their accompanying captions present 
scenes from Conrad's original text and also generate ongoing commentary whose function varies.

Since its original publication in English in 1899, the novel Heart of Darkness by the Polish-born Joseph Conrad has captivated readers with its journey into both the physical unknown of the elsewhere - in this case, the Congo River and its environs - and the psychological unknown of the other - embodied in the indigenous Congolese and also in the depths of the main characters' psyche. The novel begins aboard the Nellie on the Thames River in England as the narrator, Charles Marlow, recounts his time as a riverboat caption for a Belgian ivory company and his journey from Belgium, along the West African coast, and into the Congo by way of the Congo River. This frame narrative establishes a direct correlation between the two rivers and serves as a framework for Conrad's broader comparison of Europe and Africa and for his exploration of artificial social constructs that informed latenineteenth century notions of progress, civilization, and savagery. The climax occurs when Marlow finally encounters the elusive Mr. Kurtz whose ivory harvesting capabilities and his power over the locals rival his notoriety in the region, which had previously cast a looming and foreboding shadow over Marlow's trek deeper into the center of Africa. Later, aboard the riverboat, Marlow witnesses Kurtz's death and hears his last words, "The horror! The horror!" Despite also falling ill, Marlow recovers and, upon his return to Belgium, distributes the various documents Kurtz had entrusted to him, a process that prompts Marlow to reflect on how his journey has altered his perception of the world, of society, and of human nature. Somewhat detached and insightfully perceptive, Marlow describes the people he meets - other Europeans and Africans alike - and the various stages and events of his adventure with a contemplative clarity that serves as the basis for Conrad's critique of the West's colonial endeavor and the exploitation of manpower and resources under the guise of the civilizing mission - a line of inquiry that Stassen both addresses and problematizes through various forms of framing.

Most immediately, this new edition of Heart of Darkness is literally framed by numerous contextualizing materials in the paratext. Preceding Heart of Darkness are two short pieces: an introduction entitled "Ce que c'était que le Congo en 1898" by French historian Sylvain Venayre about the historical context of the Belgian Congo and a translation of another of Conrad's short stories also set in the Belgian Congo, "Un avant-poste du progrès", whose initial publication preceded Heart of Darkness by two years. The presence of this earlier short story in the new edition is accompanied by two of Stassen's illustrations that initiate commentary on Conrad's writing and introduce various important visual and verbal strategies carried through the treatment of 
Heart of Darkness, to which I will return shortly. Directly following Heart of Darkness are three short articles: "Postface: Coeur des ténèbres: Une histoire de couleurs" by Venayre that touches upon the relationship between Conrad and Stassen; "Sur les cartes" in which Stassen discusses his fascination with maps, particularly maps of Africa; and "A Bruxelles, la Capitale des Singes", in which Stassen analyses Charles Baudelaire's poem "La Belgique déshabillée" in conjunction with Heart of Darkness.

Taken together, these paratextual components point to a contemporary reconsideration of the original through an exploration of its blind spots and the limitations of Africanist discourse as embodied by Conrad's writing. Indeed, Stassen's dedication of the book to his daughter - "Merci à Lou, ma fille aimée, qui m'a expliqué la difference entre rien et un trou"- evokes the drive to expose and explode the silences of Conrad's text. Though Stassen's added illustrations are not comics vignettes, they nevertheless rely on framing and a dynamic interplay between images and words to produce meaning. Where we see the force of Stassen's creativity is in his choice of scenes to depict, the ways in which he frames such scenes, and the quotes and fragments of quotes he extracts from the original text to serve as captions. Turning to the two illustrations accompanying "An Outpost of Progress," we get a sense of how framing - both within the illustrations and also how the illustrations are themselves framed - drives Stassen's engagement with Conrad's writings.

Published two years before Heart of Darkness and set roughly in the same geographical location — the Belgian Congo — and the same historical period - the last decade of the nineteenth century, the short story "An Outpost of Progress" not surprisingly introduces many of the same themes central to Conrad's more well-known novel including the exploitation of natural resources and indigenous populations and European imperialism's inherent violence. The story begins when two Belgian men - Kayerts, the new manager of the outpost, and Carlier, his assistant - arrive at a remote commercial outpost in the Congo where Makola, originally from Sierra Leone, and his family work and serve as intermediaries between the indigenous population and the European company representatives. At first, Kayerts and Carlier maintain European social and cultural customs, but soon succumb to greed, corruption, and violence when Makola arranges the exchange of the outpost's indigenous work force for an impressive amount of ivory. Despite initially denouncing human-trafficking and slavery as savage, Kayerts and Carlier slowly convince themselves that they deserve their cut of the profit, rationalizing that in the ostensible emptiness of the African jungle, no one meaning European society - is present to know the truth. Awaiting the tardy return of the company's riverboat and feeling ever more removed from 
Western civilization, Kayerts and Carlier, easily irritable and paranoid, eventually turn on one another in frustration. In a demoralized and demoralizing scuffle, Kayerts shoots and kills Carlier having feared for his life. Upon realizing that Carlier was unarmed, Kayerts hangs himself just as the riverboat finally announces its arrival. In this short story, Conrad demonstrates his skepticism about the civilizing mission and investigates the repercussions and limitations of the European notion of Progress, which supposedly justified colonialism.

Stassen's two illustrations for this short story, one opposite the title page and one inserted three pages before the end introduce many important visual and textual strategies that continue throughout the illustrations for Heart of Darkness. The first situates the narrative through its depiction of the three main characters and their tropical environment. The fragment selected from the short story that captions the illustration - itself a kind of framing generates tension between the original colonial context and a contemporary postcolonial reading of the text. The caption, "[1]e personnel était complété par un nègre de Sierra Leone", comes from the short story's second sentence, but is only the first half of the sentence (11). In its entirety, the sentence continues with "qui affirmait se nommer Harry Price" and, in the following sentences, Conrad explains that, regardless of this, the indigenous Congolese gave him the name Makola, that he spoke both French and English, and that he lived with his wife and three children. Despite this rather detailed description, Stassen chooses only the first half of the sentence, effectively framing the primacy of Makola's status as "un nègre de Sierra Leone" over his preferred and bestowed names. In the illustration, Stassen centers Kayerts and Carlier smiling at each other and walking arm in arm towards Makola waiting at the outpost centered between his hut and the burial of the former outpost manager. The placement of Makola at the head of the path and centered at the top of the illustration suggests his unstated authority over the scene in spite of the arrival of the outpost's new chief. Stassen thus pits Makola's visual image against Conrad's linguistic description of him.

Stassen further emphasizes Makola's centrality and agency in the second illustration, a close-up of Makola looking fixedly at the reader, placed just before the end of the short story. In fact, this image is one of only three illustrations in the entire book that unmistakably presents a character facing the reader whose face is clearly distinguishable ${ }^{4}$. Moreover, in contrast to these

${ }^{4}$ The other two examples, found later in Heart of Darkness, are reserved for portraits of two striking men that Marlow encounters. The first presents a nighttime portrait of a brick maker who Marlow describes as a "papier-maché Mephistopheles" and who Stassen paints with a haughty expression directed at the reader. The second depicts the eccentric and youthful 
two later illustrations, the first portrait of the man from Sierra Leone, also appears the most realistic and nuanced of the three. Far from an indistinguishable blackface caricature, Stassen's detailed portrayal of this character stresses his importance in the narrative and also in the broader inner workings of the colonial system. "Est-ce votre revolver?", the man's question affixed as a caption, renders his inquisitive gaze almost accusatory and places the reader in the position of Kayerts, responsible for Carlier's murder. Purposefully framing and emphasizing both the character from Sierra Leone and his frank question, Stassen not only humanizes Conrad's African characters, but also raises the question of who is ultimately to blame for the violence, darkness, and danger of the European colonies.

As a prelude to Heart of Darkness, "An Outpost of Progress" alerts readers to the crucial nature of framing, which Stassen manipulates to foreground the interplay between presence and absence of Africa and Africans in Conrad's writing, thereby addressing often overlooked aspects of the original and creating a space in which to consider such discursive gaps or holes. Simply by selecting which scenes to illustrate and which corresponding captions to affix to them, Stassen on the one hand illustrates key moments in Heart of Darkness and, on the other hand, explores silences in the text while also engendering new ellipses meant to generate further critical inquiry.

The first image of Heart of Darkness, like the first image for "An Outpost of Progress," establishes the initial setting of the frame narrative on the Thames River and, through composition and color palette, visually evokes the solemn tone of Marlow's tale ${ }^{5}$ (36). The bottom third of the illustration depicts silhouettes of sailors smoking their pipes while listening to Marlow whose back anchors the bottom right-hand corner. In contrast to the sailors, Gravesend's city skyline hovers diagonally in the upper right-hand corner of the image across a swath of the reflective river that dominates the center of the image. The dark color palette of blacks, murky brownish-greys, and a deep, dull blue signify the night and also enhance the emotional impact of the caption in which Marlow all of a sudden exclaims that England was once also "un des endroits sombres de la terre" (36). In this example, the caption works to underline the iconic nature of the novel's opening scene, though this is not always the case.

Furthermore, whereas Stassen aligns the two illustrations in "An Outpost of Progess" along centered vertical and horizontal axes, in this

Russian devotee of Kurtz clothed in a multicolored patchwork coat that Marlow likens to a harlequin and whom he meets closer to the inner station.

5 This illustration also serves as the cover image for the entire text. 
establishing image at the beginning of Heart of Darkness, he repositions the focus along a diagonal axis that privileges the bottom left-hand corner, which becomes an important discursive site. This dynamic shift becomes a recurring technique and serves multiple purposes. First, as is the case in this example, featuring a portion of Marlow in the foreground, Stassen literally and figuratively foregrounds his point of view while also maximizing the available space within the frame in which to contextualize, enhance, problematize, and comment upon Conrad's writing. One particularly apt example of this occurs approximately a third of the way into the text and juxtaposes an extreme closeup of Marlow's shoes in the upper-right hand corner with the figure of the African worker below deck tending expertly to the furnace; Stassen suggests Marlow's point of view (72). Beyond this, the specific framing of the caption, "[i]e l'apercevais d'en haut...", a fragment from Marlow's declaration of surprise at the worker's efficiency and from his comparison of the man with a clothed dog walking on his hind legs, not only accentuates the vertical hierarchy of Marlow's gaze, but also comments on the prejudiced description of the worker. Even though Stassen paints the worker in a somewhat crouched position, thus alluding to the silhouette of a dog, he nevertheless paints a detailed figure of a human male tending to the riverboat's furnace.

Second, because all the illustrations are printed on left-handed pages, by privileging the bottom left-hand corner of the image, Stassen pulls the reader's attention away from the original text and disrupts the natural reading rhythm. It is here that Stassen often adds small details, specifically hands, feet, and blood, that redirect the reader's awareness to the violence of gaps and silences of the narrative, most notably the exorbitant number of dead Africans resulting from European colonialism and the ostensibly civilizing mission. This bottom left-hand corner thus becomes a discursive site where Stassen interjects disruptive elements that expose the limitations of Conrad's writing.

Stassen's most striking commentary on Heart of Darkness (Figure 1) captures Conrad's own critique of colonialism's inherent violence and at the same time illustrates how Conrad's style not only strips the Congolese of their humanity but also fails to adequately convey the sheer scale of devastation that resulted from European colonialism (48). In the foreground on the right is an interrupted outline of Marlow that vertically spans the entire frame while in the background African bodies are portrayed as exhausted, mistreated, and even in the process of dying. Scale and color play important roles by contributing to the overall emotional impact of the illustration. The grotesquely large drops of sweat on Marlow's face and the stunted caption, "Enfin je me trouvai sous les arbres..." become ironic in contrast to suffering in the background; that Stassen selects only a portion of the citation highlights Marlow's sense of 
physical relief from the sun. The Hell or Inferno that Marlow describes once in the shade, namely the suffering of Africans, is dramatized in Stassen's illustration. In fact, upon closer inspection, one notices that the outline of the ravine strikingly resembles the outline of the African continent at whose heart is the body of a subjugated African forever falling to his demise and, through the chains linking him to the other Africans, pulling them down with him.

Alongside the prominence of framing, intertextual references and paratextual commentary offer further postcolonial interjections that bring Conrad's text into dialogue with the imperialist narratives of the historical moment of Heart of Darkness and investigate the scope of his critique of such narratives, most readily demonstrated in the penultimate illustration of the novel that signifies Marlow's return to Belgium (112). Drawing from Charles Baudelaire's poem "La Belgique déshabillée" for inspiration, Stassen presents an average intersection in Brussels with three indistinguishable men who denote bourgeois Belgians and are pictured looking behind them, each of their faces distinctly facing away from the reader. Indeed, the almost inhuman posture of men's heads alludes directly to the line in Baudelaire's poem that posits that the men "marchent en regardant derrière eux, et se cognent sans cesse" (qtd. in Venarye, "Postface" 125). In "A Bruxelles, la Capitale des Singes," Stassen explains that, as a native Belgian, the revulsion that both Conrad and Baudelaire express for Belgium is at first upsetting, but also admirable in that it allows, what he considers, the necessary distance to unveil the anguish in the face of nothingness. For Laurent Demoulin, Stassen's treatment of this scene "rend à l'illustration sa véritable portée métalittéraire" (Demoulin 111). As Demoulin rightly suggests, the power of Stassen’s images resides in their ability to establish links across texts and across time, thus opening up the original text and its historical context to new interpretations.

Likewise, in "Sur les cartes," Stassen focuses on maps in Heart of Darkness to demonstrate how the inaccuracy of Conrad's description of maps exposes the Africanist construct of the continent. It is no surprise that Stassen would zero in on the representation of maps in Heart of Darkness for the only time in the entire text that Africa is named is during Marlow's musings on his passion for maps and, as Christopher L. Miller has argued ${ }^{6}$, the blank that becomes filled in by European explorers and imperialists is also an absence onto which Conrad and Marlow alike inscribe meaning through narrative. For Stassen, such narratives lead to a "cartographie violente qui découpe le continent en formes géométriques simplistement coloriées" (132). He

${ }^{6}$ See Chrisopher L. Miller, Blank Darkness: Darkness: Africanist Discourse in French. Chicago: University of Chicago Press, 1985. In particular chapter four, "The Discoursing Heart: Conrad's Heart of Darkness." 
dramatizes the legacy of European cartography by providing a total of six very different maps of the African continent. While most of the maps represent the changing colonial divisions of the continent, the back cover (Figure 2) of the book is the most interesting. It is a distinctively discursive map of Africa with no shapes, no lines for borders of territories, no figural representations, only names of places and geographical features in both French and Arab that evoke a spatial imprint of Africa. Each bit of nominal information takes on a particular significance for having been chosen and creates a dynamic network of spatial, historical, social, and political significance. The identification of certain regions such as Togoland, the German protectorate from 1884 until 1914, and the Independent State of the Congo, the private territory of Belgian Kind Leopold II, highlights the colonial act of naming and organizing visual representations of the continent. This unique map exposes the emptying out of the landscape — both physically and symbolically — as a necessary step for European imperialism to establish power. However, Stassen complicates the dominance of a solely European system of meaning-making by including Arabic and also other, non-European, local names (such as the Songhai Empire) to reflect the actual synchronicity of local traditions and Western narratives of history. It is not Stassen's goal to denounce outright the limitations of Conrad's work, but rather to engage with it (and by extension invite readers to do the same), so as to investigate such limitations.

In his quest to draw forth gaps, holes, and silences in Conrad's Heart of Darkness in order to reposition attention on the representation of Africa and on colonial violence, Stassen shies away from explicit portraits of Marlow and Kurtz; rather, he experiments with framing, point of view, perspective, and the dynamic interplay between the illustrations and their hand-picked captions. In contrast, with We Killed Mangy-Dog, he draws attention to and enhances the pregnant silences embedded in Honwana's masterfully subtle style. The absence of captions accompanying the illustrations in We Killed Mangy-Dog evokes a distinct quietness in contrast with the illustrations accompanying Conrad's texts. Furthermore, Stassen concentrates almost exclusively on closeups of the main characters in We Killed Mangy-Dog and eschews large-scale landscape images. Similarly, while geographical context is essential to Heart of Darkness and therefore dominates Stassen's illustrations, psychological and social complexity guide Honwana's narrative, which manifests as a contemplative exploration of characters' expressions in Stassen's illustrations for We Killed Mangy-Dog. This is not to say that Stassen neglects the landscape, but rather that is plays a secondary role to the representation of the characters.

The silences in We Killed Mangy-Dog differ from those in Heart of Darkness; rather than expose narrative blind spots as is the case with Conrad's 
writings, they function as a kind of calculated observation. Honwana's writing purposefully invites readers to fill in the silences, thus engaging on a personal level with the narrative. Irene Marques accurately describes his style "as the acute optical surveillance of a failed regime that dehumanizes both oppressed and oppressor: it functions as the literal mirror of oppression, self-oppression, unconsciousness, humiliation and trauma" (127) and goes on to argue that his "writing is indeed the 'eye' that accuses and incites" (129). Indeed, eyes and the gaze, highly thematized by Honwana, figure prominently in Stassen's illustrations.

\section{2) Eyeing the Silence in We Killed Mangy-Dog}

We Killed Mangy-Dog, a political allegory about the injustices and inequality of Portuguese colonialism in Mozambique just before independence, was originally published in 1964 as the title piece in a larger collection of seven total short stories by Honwana entitled, We Killed Mangy Dog and Other Stories?. Choosing characters from different ethnic and social backgrounds as the focus of each short story, Honwana weaves a multifaceted tapestry of the daily struggles of Mozambicans under Portuguese rule. We Killed Mangy-Dog, the first and longest of the seven short stories, told from the point of view of Ginho, a young black boy, recounts how, under orders from the local colonial administrator, M. Duarte, a veterinarian, tasks Ginho and his fellow schoolmates with killing Mangy-Dog, a decrepit and diseased dog that resides in the school yard and whose only friend is a unbalanced girl named Isaura. Initially, Ginho is delighted at having been considered as part of the group as his socially marginal status often precludes him from actively participating in other activities such as playing soccer. However, as the boys' fear and hesitation mount when faced with actually killing Mangy-Dog, Ginho, along with Isaura who attempts to save Mangy-Dog, become symbolic targets of the other boys' verbal aggression. In the end, though the inclusive plural pronoun of the title implies Ginho's participation in murdering Mangy-Dog, he and Isaura cling to one another during the actual violent event.

Honwana capitalizes on the choice of an innocent narrator to stage a critique of Portuguese colonial rule in Mozambique while also demonstrating the ethnic and cultural richness of the region. As a political allegory, the cast of characters metonymically stand in for all of Mozambican society; Ginho's schoolmates each come from a different ethnic background as indicated by their names while each of the small handful of adults in the story symbolically represent various colonial institutions, populations, and important concepts.

\footnotetext{
${ }^{7}$ In the same year, Honwana was imprisoned until 1967 for his participation in the Mozambican Liberation Front.
} 
For example, the schoolmistress not only serves as a paragon of the colonial school system, but also voices and enforces social norms and proper etiquette. Similarly, while the other healthy dogs echo Ginho's schoolmates, Mangy-Dog incarnates the diseased corruption, violence, and injustice of Portuguese colonial rule. Using Ginho's youthful ignorance and innocence, Honwana deploys repetition and deceptively simple descriptions undoubtedly laden with multiple meanings to condemn the status quo. Furthermore, he generates tension between seeing as a form of witnessing and acting as an expression of power through the central themes of eyes and speaking. Consequently, silence and that which is unspoken both play a central role throughout the short story and also inform how Stassen approaches the illustrations, which complement and echo Honwana's literary strategies by functioning on multiple levels.

The physical makeup of Stassen's version of We Killed Mangy-Dog underlines this fact since, in contrast to his treatment of Heart of Darkness, there is essentially no contextualizing material save a short plot summary on the back cover that also describes Stassen's contribution as a "regard lucide". In addition, though the rich quality of the cover and pages suggests an artist's book much like the version of Heart of Darkness, the book's small format, approximately six-and-a-half inches squared, places it more along the lines of an expensive children's book. This affinity with children's literature emphasizes that We Killed Mangy-Dog is told from Ginho's point of view, which foregrounds children's quotidian experiences and Stassen furthers this link through subject matter and layout in his illustrations. Almost all of the sixteen images prominently feature children — Ginho, Isaura, and the other boys form school - and Mangy-Dog who Stassen paints with rather simple shapes and large eyes. Equally, for each of the sixteen illustrations that fall on the recto almost every five pages, Stassen employs a brighter color palette dominated by vibrant, clear blues (a deliberately symbolic choice discussed below) and rich gold tones and uses a generally more simplified layout than in Heart of Darkness as exemplified in the illustration that introduces Isaura pictured in the foreground on the right-hand side of the image and whose head is distinctly haloed by the sun (15). The bright orange sky and gold sun generate a somewhat monochromatic schoolyard against which the light blue school uniforms of Isaura and Ginho (seated in the background with the schoolmistress's heeled foot asserting her presence just behind him) pops.

Though the prominence of simple outlines and flat, gouache colors suggest a naïve simplicity, Stassen's approach mimics Honwana's multilayered original text. Indeed, this illustration of Isaura with Ginho in the background proves much more complex than it might seem. In conjunction with the symbolic halo provided by the sun, the illustration's placement in the text as 
the only one out of sequence highlights Isaura's unique saintliness as the only character that cares for Mangy-Dog. In addition, the blue of her shirt coupled with her overly-large eyes align her with Mangy-Dog. Honwana begins $W e$ Killed Mangy-Dog with a detailed description of Mangy-Dog's eyes, a description that bears reproducing for, in addition to setting the tone of the short story, it recurs multiple times and with each refrain, reinforcing the human quality of Mangy-Dog and his suffering:

Le Chien Teigneux avait des yeux bleus qui ne brillaient pas, mails ils étaient immenses et toujours pleins de larmes qui coulaient sur son museau. Ils faisaient peur, ces yeux, si grands, qui regardaient comme quelqu'un qui demanderait quelque chose sans vouloir le dire. (5)

Though Isaura has brown eyes, the choice of blue for her uniform evokes Mangy-Dog's eyes and, though not as terrifying as Mangy-Dog, Isaura also provokes uneasiness in others because of her unfocused gaze and general lack of coherent speech. Stassen picks up the correlation between the two in later illustrations. For example, in an extreme close-up of Mangy-Dog licking Ginho's shoes, his eyes resemble those of Isaura (43). Then later when Isaura throws herself on Mangy-Dog in an attempt to save him, Stassen depicts the two together with twinned terrified expressions (79).

Even more subtle in the saintly illustration of Isaura are the presence and comportment of Ginho and the schoolmistress. Ginho's less prominent stature suggests his initial ambivalence towards both Isaura and Mangy-Dog, though his attentive gaze on Isaura hints at his interest in the two and his eventual identification with them. Just as Stassen pictures Isaura and MangyDog together, he places Ginho in close proximity to Mangy-Dog on multiple occasions, the last of which shows the other boys singling Ginho out alongside Mangy-Dog in the clearing where Mangy-Dog is to be killed (67). In contrast to the emotive depictions of Isaura and Ginho, Stassen selects only a heeledfoot to metonymically represent the schoolmistress. While this choice derives from Ginho's repeated descriptions of the schoolmistress walking back and forth behind him during recess, it also characterizes Stassen's treatment of the adults in We Killed Mangy-Dog.

On the rare occasions when adults figure in the illustrations, Stassen purposefully inhibits direct access to them in much the same way he avoids depicting Marlow and Kurtz outright in Heart of Darkness. As with the small detail located in the bottom left-hand corner of the illustrations in Heart of Darkness, the schoolmistress's heeled-foot wields immense authority when presented. However, rather than point to countless silence victims as is the case in Heart of Darkness, it signifies the school's cultural hegemony and suggests constant surveillance of the local population under the Portuguese's 
rule. Likewise, in the illustrations of the local administrator and M. Duarte, the veterinarian, Stassen frames them in such a way as to demonstrate their power over others in spite of the fact that their faces are obscured. This strategy underlines Ginho's perspective as subordinate to the adults and, through abstraction, it also supports how Honwana crafts archetypal characters that enable a multilayered reading of We Killed Mangy-Dog.

Whereas Stassen alludes to a poem by Baudelaire in Heart of Darkness and thus establishes a continuity in the literary representations of Brussels at the end of the nineteenth century, in We Killed Mangy-Dog, through visual references to his award-winning bande dessinée about the 1994 Rwandan genocide, Déogratias (2000), he suggests a correlation between the corruption of Portuguese colonial rule in Mozambique and the atrocities of the Rwandan genocide. The narrative similarities between We Killed Mangy-Dog and Déogratias are evident: both center on the lives of children and their coming of age, both feature young people as killers, and both make extensive use of anthropomorphized dogs as metaphors for dehumanized figures. The illustrations that most effectively allude to Stassen's work on the Rwandan genocide are, rightly so, those of Ginho, Isaura, and Mangy-Dog since their fates are intertwined and their suffering is related. These images are very much evocative of the exorbitant number of frames in Dégratias of the main character's traumatized expression and, in a similar fashion, elicit a deeper probing into the characters' psychological state. As discussed above, the first image of Isaura foreshadows her attempt to save Mangy-Dog from being murdered and, during the climax of the story, in two separate illustrations, both Ginho and Isaura are depicted with Mangy-Dog, subsequently cast into the role of the victim, and therefore sharing in Mangy-Dog's terror. During the actual murder of Mangy-Dog at the hands of the other boys, Ginho and Isaura cling to one another and Honwana punctuates the scene's violence with a paradox; describing the shooting, Ginho explains that "même les yeux fermés, je voyais sauter les canons des carabines" (84). Subsequently, rather than directly show Mangy-Dog's violent death, Stassen takes his cue from Honwana's subtle style and illustrates, in a close-up of Ginho's and Isaura's eyes, the fire from the rifles reflecting in Ginho's pupils (85). By way of such visual intertextuality, the choice of illustrating Honwana's text draws a direct link between European colonialism and postcolonial violence across subSaharan Africa.

\section{3) Conclusion}

Turning to a close reading of Stassen's differing paratextual practices in the new editions of Heart of Darkness and We Killed Mangy-Dog, this article 
examined how his additions and interjections explored silences at work in the original texts. In Heart of Darkness, Stassen experiments with framing as a textual practice and as a guiding principle for the composition of the added splash page illustrations and their carefully extracted captions. Physically framing Conrad's text with a plethora of essays and subsequent materials to situate the narrative historically, Stassen and historian Sylvain Venayre alert readers the text's original context, all of which provides an important foundation for Stassen's attempt to draw attention to gaps, holes, and discrepancies in Conrad's presentation of Africa and the indigenous population. Additionally, the placement of each illustration on the left-hand page actively counteracts the normal process of reading Conrad's text. Likewise, through formal conventions of framing, scale, point of view, and by privileging the lower left-hand corner of the illustrations, Stassen packs each illustration with subtle details that, when coupled with their selected captions, refocus the reader's attention on often obscured elements of Heart of Darkness.

Conversely, with Luis Bernardo Honwana's We Killed Mangy-Dog, Stassen eschews extensive framing material focusing rather on an evocative interpretation of Honwana's literary style and strategies. At the level of form, the small, almost square construction of the book and the ostensibly more simplistic square illustrations suggest that this new edition is a children's book-a deliberate textual practice that acknowledges the original text's multiple layers of interpretation as a political allegory for though it is told from the point of view of young Ginho, much more adult concepts underscore the entire text. At the level of content, Stassen also takes his cue from Honwana's own style by thematizing eyes, sight, and witnessing, thus establishing visual links between the three main characters and their marginalization under Portuguese colonial rule.

Though it has become a mainstream tendency to adapt canonical and well-known texts (mainly novels) into bande dessinée form, Stassen has chosen, rather, to illustrate original texts and thus comment upon them. In Heart of Darkness, he experiments with various forms of framing to interrupt Conrad's writing and to problematize his representations of Africa and the indigenous populations ${ }^{8}$. In We Killed Mangy-Dog, Stassen playfully mimics the multilayered nature of Honwana's political allegory to emphasize his subtle condemnation of Portuguese colonial rule. In both cases, the illustrations interfere with the

\footnotetext{
${ }^{8}$ In this regard, Stassen participates in a broader trend in European cultural production and academic research in which, by returning to the colonial era with a critical eye, writers, artists, filmmakers, and musicians augment existing archives to reconfigure official narratives.

Examples include novels by French writer Didier Daeninckx and the interdisciplinary research of French historians Pascal Blanchard and Nicolas Bancel.
} 
textual mode of the original texts; this subversion of the primacy of writing with regards to visual representations implies Stassen's self-stated goal of wanting to abolish the hierarchy between literature and bandes dessinées (Ciment 115). However, the reality of the situation, as Laurent Demoulin explains in "Du Rwanda au Coeur des ténèbres. Jean-Philippe Stassen illustre Conrad" is such that Stassen's versions of Conrad and Honwana's texts are usually sold in specialty stores; in the rare cases they are in mainstream bookstores such as FNAC', they are not in the literature section under Conrad and Honwana's names, but, rather, housed under Stassen's name in the bande dessinée section (Demoulin 106). A quick online search reveals that the same is true of FNAC's website.

Ultimately, Stassen's treatment of Honwana's and Conrad's respective texts functions as an ongoing dialogue with European colonialism in Africa. Whereas in his earlier bandes dessinées he focused more on the contemporary moment and the complexities of identity in a globalized world from a European vantage point, with these two illustrated texts, Stassen goes back to the nineteenth and earlier twentieth centuries investigating colonial systems of logic to understand better both the historical moments in and of themselves and, more importantly, their sustained bearing on contemporary politics, thus drawing parallels across geographic spaces and historical eras. Similarly, just as these texts are meant to challenge the hierarchy of the purely linguistic mode, they also represent Stassen's attempt to decolonize the logic of the colonizer.

That Stassen chose a canonical colonial text written by a European (Conrad) and a text written on the eve of Mozambican independence from the point of view of a Mozambican under Portuguese colonial rule (Honwana) is telling of the entirety of his overhauling of colonial discourse. Furthermore, though Conrad's text was originally published in English and Honwana's in Portuguese, these new translated editions target a specifically francophone audience while underlining the prevalent character of European colonialism, the ubiquity of European colonial epistemology, and its lasting legacy on Western representations of Africa. Ultimately, Stassen's illustrations generate a dialogue between text and image and across time and space to rethink

${ }^{9}$ The Fédération Nationale d'Achats des Cadres or FNAC, a well-known and large-scale retail chain in France, serves as a hub of cultural dissemination as it functions as a bookstore and an electronics store while simultaneously serving as a public venue for cultural events including book signings, concerts, and interviews and meet and greet type events with artists, writers, musicians, and actors. Additionally, FNAC also hosts a book fair each year that includes a literary prize; produces music compilations of new artists; serves as a ticket vendor for concerts and events at various venues; and sponsors numerous cultural events throughout France (including, in the past, the annual International Bande Dessinée Festival in Angoulême). 
Alternative Francophone vol.1, 8(2015):18-36

http://ejournals.library.ualberta.ca/index.php/af

European colonialism, imperialism, and their continuing modes of representation. 


\section{Works Cited}

Ciment, Gilles and Thierry Groensteen. "Itinéraire: Entretien avec JeanPhilippe Stassen." 9 Art 7 (2002): 108-121.

Conrad, Joseph, Jean-Philippe Stassen, and Sylvain Venayre. Coeur des ténèbres: Précédé d'un avant-poste du Progrès. Paris: Futuropolis-Gallimard, 2006.

Conrad, Joseph, Morton D. Zabel, ed.. Youth: A Narrative and Two Other Stories. New York: Doubleday, 1959.

Demoulin, Laurent. "Du Rwanda au Caur des ténèbres. Jean-Philippe Stassen illustre Conrad." Textyles, 36-37 (2010) 101-116.

Genette, Gerard. Paratexts: Thresholds of Interpretation. Trans. Jane E. Lewin. Cambridge: Cambridge University Press, 1997.

Honwana, Luís Bernardo, Jean-Philippe Stassen and Michel Laban, trans. Nous avons tué le Chien Teigneux Paris: Editions Chandeigne, 2006

Marques, Irene. "The Mirror of Colonial Trauma in Honwana's Short Stories: The 'eye' That Accuses and Incites." African Identities. 6.2 (2008): 127147.

Miller, Christopher L. Blank Darkness: Africanist Discourse in French. Chicago: University of Chicago Press, 1985. 


\section{Figures}

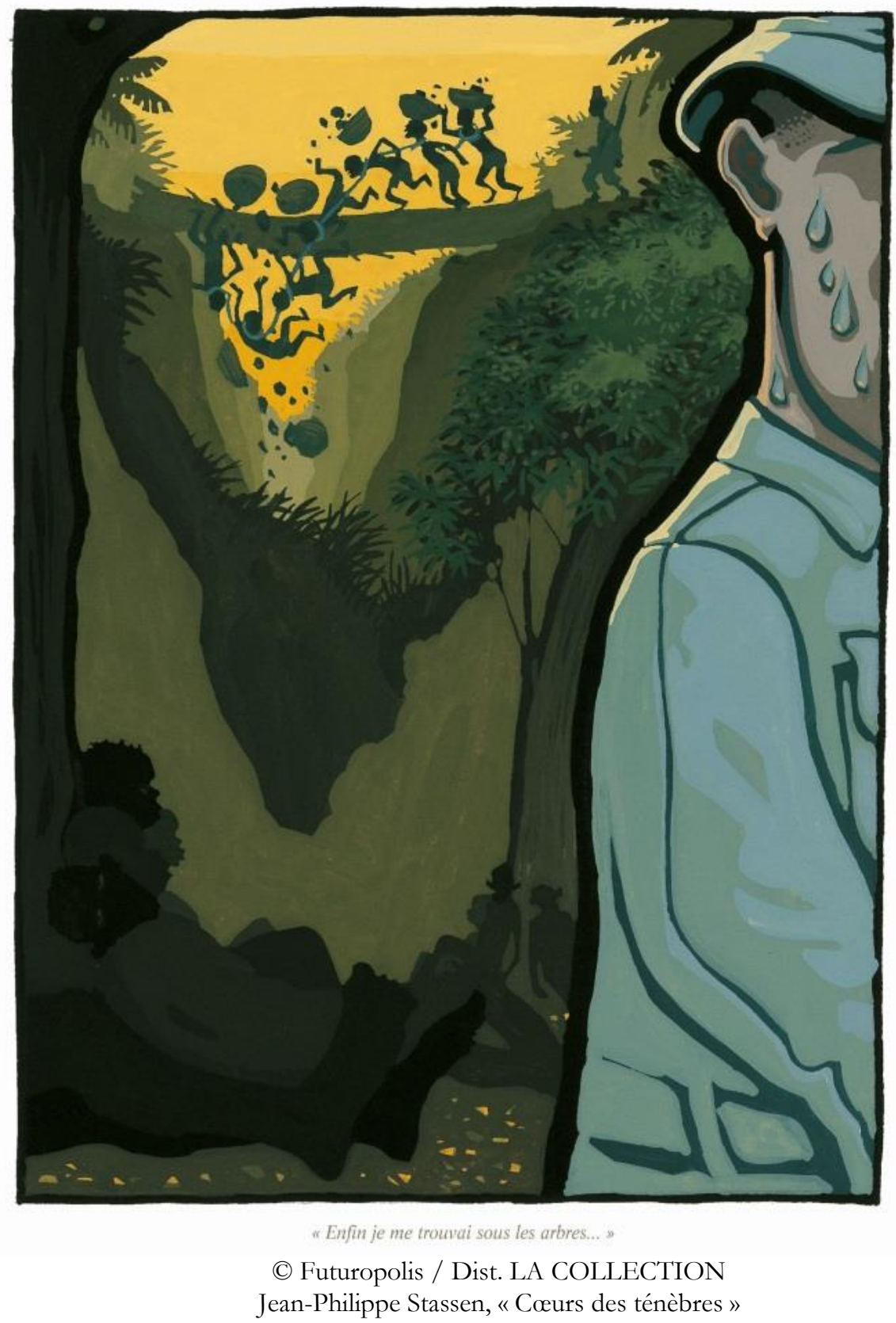

Figure 1. Marlow's relief in the shade. Joseph Conrad, Jean-Philippe Stassen and Sylvain Venayre, Coeur des ténèbres: Précédé d'un avant-poste du Progrès. Paris: Futuropolis-Gallimard, 2006), 48. 


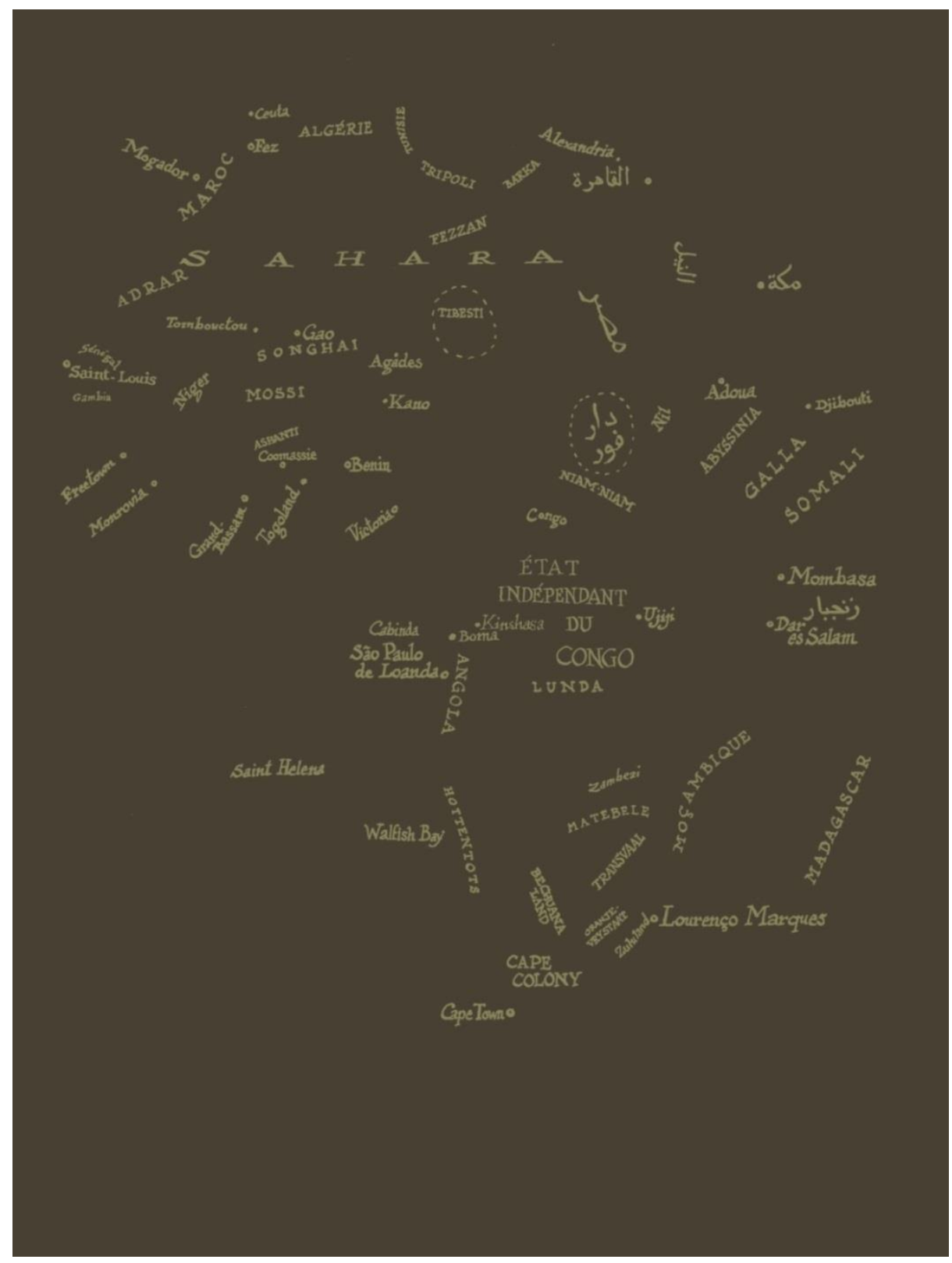

(C) Futuropolis / Dist. LA COLLECTION

Jean-Philippe Stassen, « Cœurs des ténèbres »

Figure 2. Back cover of Caur des ténèbres. (Joseph Conrad, Jean-Philippe Stassen and Sylvain Venayre, Coeur des ténèbres: Précédé d'un avant-poste du Progrès. Paris: Futuropolis-Gallimard, 2006). 